九州大学学術情報リポジトリ

Kyushu University Institutional Repository

\title{
Growth and Photosynthetic Efficiency of Two Lettuce Cultivars Under Light-Emitting Diode Monochromatic Light
}

TSAI, Chun-Yu

Agriculture Science, National Chiayi University : Ph. D. Program

YEN, Yung-Fu

Department of BioAgricultural Science, National Chiayi University

AY, Chyung

Department of BioAgricultural Science, National Chiayi University

MIYAJIMA, Ikuo

Institute of Tropical Agriculture, Kyushu University

他

https://doi.org/10.5109/4363546

出版情報: 九州大学大学院農学研究院紀要. 66 (1)，pp.11-20，2021-03-01. Faculty of Agriculture， Kyushu University

バージョン :

権利関係 : 


\title{
Growth and Photosynthetic Efficiency of Two Lettuce Cultivars Under Light-Emitting Diode Monochromatic Light
}

\author{
Chun-Yu TSAI ${ }^{1}$, Yung-Fu YEN ${ }^{2}$, Chyung AY $^{3}$, \\ Ikuo MIYAJIMA ${ }^{4}$ and Kuang-Liang HUANG ${ }^{5 *}$ \\ Institute of Tropical Agriculture, Kyushu University, \\ Fukuoka 819-0395, Japan \\ (Received October 19, 2020 and accepted November 4, 2020)
}

\begin{abstract}
This study discussed the influence of light-emitting diodes (LEDs) with red, blue, green, and yellow light on the growth and photosynthetic efficiency of Boston lettuce and Ziyan lettuce as a reference for lettuce production in plant factories. The experiments were conducted in a plant factory under a $120 \mu \mathrm{mole} \cdot \mathrm{m}^{-2} \cdot \mathrm{s}^{-1}$ photosynthetic photon flux density, $\mathrm{CO}_{2}$ concentration of $1000 \mathrm{ppm}$, and daytime and nighttime temperature of $25^{\circ} \mathrm{C} / 18 \mathrm{~h}$ and $17^{\circ} \mathrm{C} / 6 \mathrm{~h}$, respectively. The experiment results revealed that after 15 days of treatment under different spectral qualities, the appearances of the two lettuce leaves differed slightly. The fresh and dry weights of the Boston lettuce were highest under green light treatment. The fresh and dry weights of the Ziyan lettuce were higher under red and green light, and blue light helped the leaves to change color. In addition, photosynthesis analyzers were used to investigate the photosynthetic efficiency of the two types of lettuce under the four spectral qualities under the six luminous intensity levels of $20,40,60,80,100$, and $120 \mu \mathrm{mole} \cdot \mathrm{m}^{-2} \cdot \mathrm{s}^{-1}$ and six $\mathrm{CO}_{2}$ concentrations of 400, 600, 800, 1000, 1200, and $1400 \mathrm{ppm}$. The photosynthetic efficiency of the two types of lettuce generally increased with increasing luminous intensity and $\mathrm{CO}_{2}$ concentration. When the luminous intensity was 100 and $120 \mu \mathrm{mole} \cdot \mathrm{m}^{-2} \cdot \mathrm{s}^{-1}$ and the $\mathrm{CO}_{2}$ concentration was $1200 \mathrm{ppm}$ and $1400 \mathrm{ppm}$, the Boston lettuce had the highest photosynthetic efficiency under green light. When luminous intensity was $120 \mu \mathrm{mole} \cdot \mathrm{m}^{-2} \cdot \mathrm{s}^{-1}$ and the $\mathrm{CO}_{2}$ concentration was over $1000 \mathrm{ppm}$, the Ziyan lettuce had the highest photosynthetic efficiency under red light. These results revealed that the monochromatic LED light most suitable for growth differed across types of lettuce. In this experiment, the yield and photosynthetic efficiency of Boston lettuce were highest under green light. Those of Ziyan lettuce were highest under red light.
\end{abstract}

Key words: Lactuca sativa, light-emitting diode (LED), plant factory, spectral quality

\section{INTRODUCTION}

Light is a basic factor for the growth and development of plants. It is the basic energy source for photosynthesis and a key regulatory factor for the growth and development of plants. Plant growth is influenced by light intensity and different spectral qualities and radiation ratios ( $\mathrm{Xu}$ et al., 2015). Photosynthesis can be divided into three stages: (1) photochemistry, (2) electron shuttle, and (3) carbon metabolism. The stages are connected inside the thylakoid membrane, and different spectrums are absorbed. For plants to conduct photosynthesis, chlorophylls must receive certain light intensity. If the light intensity is insufficient, electron transmission is limited. Thus, adaptations for photosynthetic control of light should include increasing photosynthetic efficiency, opening and closing stomata, and decent nutrient components, germination, leaf weight, and plant defense. (Dutta, 2017; Pettersen et al., 2010). Louis et

\footnotetext{
Ph.D. Program of Agriculture Science, National Chiayi University, Chiayi 60004, Taiwan, Republic of China

2 Department of BioAgricultural Science, National Chiayi University, Chiayi 60004, Taiwan, Republic of China

Department of Biomechatronic Engineering, National Chiayi University, Chiayi 60004, Taiwan, Republic of China

${ }^{4}$ Institute of Tropical Agriculture, Kyushu University, Fukuoka 819-0395, Japan

${ }^{5}$ Department of Horticultural Science, National Chiayi University, Chiayi 60004, Taiwan, Republic of China

* Corresponding author: (Email: klhuang@mail.ncyu.edu.tw)
}

al. (2000) controlled the light source of lettuce production using multiple methods and confirmed that lettuce yield is closely related to photosynthetic photon flux density. In the past, high pressure sodium lamps were mainly used for the electric lighting treatment of greenhouse crops; however, the lights cannot be turned on and off quickly. By contrast, light-emitting diodes (LEDs) have the advantage of precise control of light intensity and spectral quality for fast control. Thus, the market value of plants increases, and the production cost of electricity is reduced (Van Iersel and Gianino, 2017).

Hernández and Kubota (2016) mentioned that LEDs have been a necessary light source for plant growth in previous research. However, research on the influence of LED light intensity and spectral quality on plant growth and development is limited. Illumination experiments have mainly used red light and blue light (Olle and Vkvilé, 2013). Mizuno et al. (2011) used red light LED to grow cabbages and reported that the anthocyanin content of the red cabbages increased. Li et al. (2012) used blue and red LED combinations with a light intensity of $80 \mu \mathrm{mole} \cdot \mathrm{m}^{-2} \cdot \mathrm{s}^{-1}$ on kale. Kale has high amount of chlorophylls, and blue LED light is beneficial to its nutrient growth and increases its vitamin $\mathrm{C}$ content. Rabara et al. (2017) noted that red LED light facilitated the growth and development of three types of artichoke seedlings. The yield increased by $22 \%-97 \%$ over those from general greenhouses, which indicated the importance of red light for the indoor growth of arti- 
Table 1. Spectral energy distribution of monochromatic light-emitting diode light

\begin{tabular}{lrrrrr}
\hline \multirow{2}{*}{\begin{tabular}{l} 
Photosynthetic Photon \\
\multicolumn{2}{c}{ Flux Density (PPFD) }
\end{tabular}} & \multicolumn{5}{c}{ Spectral distribution ratio (\%) } \\
\cline { 3 - 6 } & \multicolumn{2}{c}{ Red } & Blue & Green & Yellow \\
\hline Red & $(610-780 \mathrm{~nm})$ & 88.67 & 0.09 & 0.39 & 4.11 \\
\hline Blue & $(450-500 \mathrm{~nm})$ & 0.04 & 68.14 & 1.10 & 0.03 \\
\hline Green & $(500-570 \mathrm{~nm})$ & 0.19 & 10.59 & 87.90 & 1.73 \\
\hline Yellow & $(570-590 \mathrm{~nm})$ & 13.75 & 0.02 & 2.57 & 54.47 \\
\hline \multicolumn{2}{c}{ Red : Blue $=2: 1$} & 60.88 & 38.54 & 0.41 & 0.08 \\
\hline
\end{tabular}

chokes. In addition, growing cucumbers with red LED light resulted in higher stem fresh weight and dry weight (Hernández and Kubota, 2012). Using far infrared radiation $(730 \mathrm{~nm})$ with red light $(640 \mathrm{~nm})$ to grow red leaf lettuce with a light intensity of $300 \mu \mathrm{mole} \cdot \mathrm{m}^{-2} \cdot \mathrm{s}^{-1}$ caused leaves to become elongated and increased their yield. In addition, their anthocyanin content and antioxidation potential were inhibited (Stutte et al., 2009).

For lettuce growing in a regular greenhouse, the leaves of different cultivars present different colors. Under a natural light source, the full spectrum can be provided; thus, plant growth can show its original characteristics. However, few studies have examined the influence of single spectral qualities on plant growth, particularly yellow light and green light. This study discussed the influence of single-light LEDs with different light intensity and $\mathrm{CO}_{2}$ concentration on the growth and photosynthetic efficiency of two lettuce cultivars as a reference for lettuce production in plant factories.

\section{MATERIALS AND METHODS}

\section{Plant materials and nursery environment}

This experiment selected two cultivars of lettuce (Lactuca sativa). These were green leaf Boston lettuce purchased from Formosa Farming Material Co., Ltd and red leaf Ziyan lettuce from Known-You Seed Co., Ltd.

To cultivate seedlings, the seeds were first immersed in water for $2 \mathrm{~h}$. They were planted on rock wool for one day in closed plastic containers to hasten gemination. The sprouting seeds were selected and placed in plant factories that can control the temperature and $\mathrm{CO}_{2}$ level (length of $6.07 \mathrm{~m}$, width of $2.47 \mathrm{~m}$, height of $2.4 \mathrm{~m}$ ). The red and blue LED light ratio was $2: 1$, with a light intensity of $120 \mu \mathrm{mole} \cdot \mathrm{m}^{-2} \cdot \mathrm{s}^{-1}$ and $\mathrm{CO}_{2}$ concentration of $1000 \mathrm{ppm}$. With cycled gully nutrient solution control through the nutrient film technique, the nutrient solutions consisted of A solution and B solution. A liter of A solution contained $34 \mathrm{~g}$ of $\mathrm{KH}_{2} \mathrm{PO}_{4}, 39.8 \mathrm{~g}$ of $\mathrm{KNO}_{3}, 97.28 \mathrm{~g}$ of $\mathrm{MgSO}_{4}, 52.48 \mathrm{~g}$ of $\mathrm{K}_{2} \mathrm{SO}_{4}$; it also contained micro elements of $22 \mathrm{~g}$ of $\mathrm{MnSO}_{4}, 29 \mathrm{~g}$ of $\mathrm{HBO}_{3}, 14 \mathrm{~g}$ of $\mathrm{ZnSO}_{4}$, $1.8 \mathrm{~g}$ of $\mathrm{CuSO}_{4}$, and $1.2 \mathrm{~g}$ of $\mathrm{Na}_{2} \mathrm{MoO}_{4}$. A liter of B solution contained $144.7 \mathrm{~g}$ of $\mathrm{Ca}\left(\mathrm{NO}_{3}\right)_{2}, 16.54 \mathrm{~g}$ of $\mathrm{NH}_{4} \mathrm{NO}_{3}$, $39.8 \mathrm{~g}$ of $\mathrm{KNO}_{3}$, and $1.86 \mathrm{~g}$ of ferric ethylenediaminetetraacetic acid. When preparing the solutions, $600 \mathrm{~mL}$ of A and B solution were diluted to $120 \mathrm{~L}$ of water, and the electrical conductivity value was adjusted to 230$250 \mu \mathrm{S} / \mathrm{cm}$ with a $\mathrm{pH}$ value of 5.8-6.5. The indoor day- time temperature was set as $25^{\circ} \mathrm{C} / 18 \mathrm{~h}$, and the nighttime temperature was set as $17^{\circ} \mathrm{C} / 6 \mathrm{~h}$. The seedlings were grown for 7 days as the experiment materials.

\section{Experiment methods}

1. In the experiment, the Spectral Quantum Spectrophotometer manufactured by Lebio in Taiwan was used to measure the spectrum energy distribution of four LED lights with different spectral qualities. Only the spectral qualities were changed, whereas other environment conditions remained identical. The experiment was conducted with a red light (610-780 nm), blue light (450-500 nm), green light (500-570 nm), and yellow light (570-590 nm; Table 1).

2. Plant sampling analysis: The first sampling was conducted on the 6th day of the experiment. Then, sampling was conducted every 3 days for a total of four samplings. In each sampling, the leaf length, width, fresh weight, and appearance were observed. Then, the plants were covered with aluminum foil and placed in an oven to dry for 1 day at $80^{\circ} \mathrm{C}$ before being measured for dry weight. The measurement was repeated 3 times with one plant each time.

3. Plant photosynthetic efficiency analysis: On the 12th day of the experiment, the plant leaf area was approximately $6 \mathrm{~cm}^{2}$. The LI-6400XT Portable Photosynthesis System manufactured by LI-COR in the United States was used to analyze the photosynthetic efficiency of the leaves. Analytic clamps were used to clamp the leaves. For the different spectral qualities, the light intensity was 20, 40, 60, 80, 100, and $120 \mu \mathrm{mole} \cdot \mathrm{m}^{-2} \cdot \mathrm{s}^{-1}$. The $\mathrm{CO}_{2}$ concentration was $400,600,800,1000,1200$, and 1400 ppm. The measurement was repeated 3 times with one plant each time.

\section{Statistic data analysis}

The data was compiled with Microsoft Excel, and the differences in growth under different spectral qualities were investigated. In addition, the Scheffe test of the SAS program was used to verify significant differences in the data with different spectral qualities.

\section{RESULTS}

\section{Plant sampling analysis}

Table 2 and Fig. 1 indicate the results from the dif- 
Table 2. Growth performance of Boston lettuce under a light intensity of $120 \mu \mathrm{mole} \cdot \mathrm{m}^{-2} \cdot \mathrm{s}^{-1}$ and $\mathrm{CO}_{2}$ concentration of 1000 ppm measured by day after planting and monochromatic light-emitting diode light

\begin{tabular}{clcccc}
\hline $\begin{array}{c}\text { Days after } \\
\begin{array}{c}\text { Planting } \\
\text { (Day) }\end{array}\end{array}$ & Spectrum & $\begin{array}{c}\text { Fresh weight } \\
(\mathrm{mg} / \mathrm{plant})\end{array}$ & $\begin{array}{c}\text { Dry weight } \\
(\mathrm{mg} / \mathrm{plant})\end{array}$ & $\begin{array}{c}\text { Leaf length } \\
(\mathrm{cm})\end{array}$ & $\begin{array}{c}\text { Leaf width } \\
(\mathrm{cm})\end{array}$ \\
\hline \multirow{3}{*}{6} & Red & $742.5 \mathrm{a}^{\mathrm{z}}$ & $50.4 \mathrm{ab}$ & $8.47 \mathrm{a}$ & $2.43 \mathrm{ab}$ \\
& Blue & $679.7 \mathrm{ab}$ & $53.4 \mathrm{a}$ & $7.88 \mathrm{a}$ & $2.52 \mathrm{a}$ \\
& Green & $609.7 \mathrm{~b}$ & $45.0 \mathrm{~b}$ & $7.66 \mathrm{a}$ & $2.34 \mathrm{ab}$ \\
& Yellow & $457.1 \mathrm{c}$ & $28.2 \mathrm{c}$ & $8.22 \mathrm{a}$ & $2.02 \mathrm{~b}$ \\
\hline \multirow{3}{*}{9} & Red & $1279.5 \mathrm{bc}$ & $83.0 \mathrm{~b}$ & $11.46 \mathrm{~b}$ & $3.15 \mathrm{ab}$ \\
& Blue & $1707.1 \mathrm{a}$ & $109.8 \mathrm{a}$ & $12.60 \mathrm{a}$ & $3.68 \mathrm{a}$ \\
& Green & $1415.1 \mathrm{ab}$ & $80.8 \mathrm{~b}$ & $12.50 \mathrm{a}$ & $3.26 \mathrm{ab}$ \\
& Yellow & $1054.6 \mathrm{c}$ & $57.4 \mathrm{c}$ & $12.31 \mathrm{a}$ & $2.59 \mathrm{~b}$ \\
\hline \multirow{3}{*}{12} & Red & $4213.7 \mathrm{a}$ & $285.0 \mathrm{a}$ & $14.93 \mathrm{~b}$ & $4.52 \mathrm{ab}$ \\
& Blue & $3073.1 \mathrm{~b}$ & $170.7 \mathrm{bc}$ & $16.04 \mathrm{a}$ & $5.03 \mathrm{a}$ \\
& Green & $3053.3 \mathrm{~b}$ & $175.5 \mathrm{~b}$ & $15.74 \mathrm{ab}$ & $3.87 \mathrm{~b}$ \\
& Yellow & $2173.1 \mathrm{c}$ & $117.2 \mathrm{c}$ & $15.02 \mathrm{~b}$ & $3.64 \mathrm{~b}$ \\
\hline \multirow{2}{*}{15} & Red & $5467.6 \mathrm{~b}$ & $290.1 \mathrm{~b}$ & $15.56 \mathrm{c}$ & $4.38 \mathrm{~b}$ \\
& Blue & $3938.6 \mathrm{c}$ & $228.0 \mathrm{~b}$ & $17.52 \mathrm{~b}$ & $5.41 \mathrm{a}$ \\
& Green & $7781.0 \mathrm{a}$ & $448.5 \mathrm{a}$ & $18.97 \mathrm{a}$ & $5.57 \mathrm{a}$ \\
& Yellow & $4185.0 \mathrm{bc}$ & $243.9 \mathrm{~b}$ & $18.36 \mathrm{ab}$ & $4.83 \mathrm{ab}$ \\
\hline
\end{tabular}

${ }^{\mathrm{z}}$ Mean separation within the same column followed by different lowercase letters were significantly different $(\mathrm{p}<0.05)$, as determined through Scheffe's multiple range test.

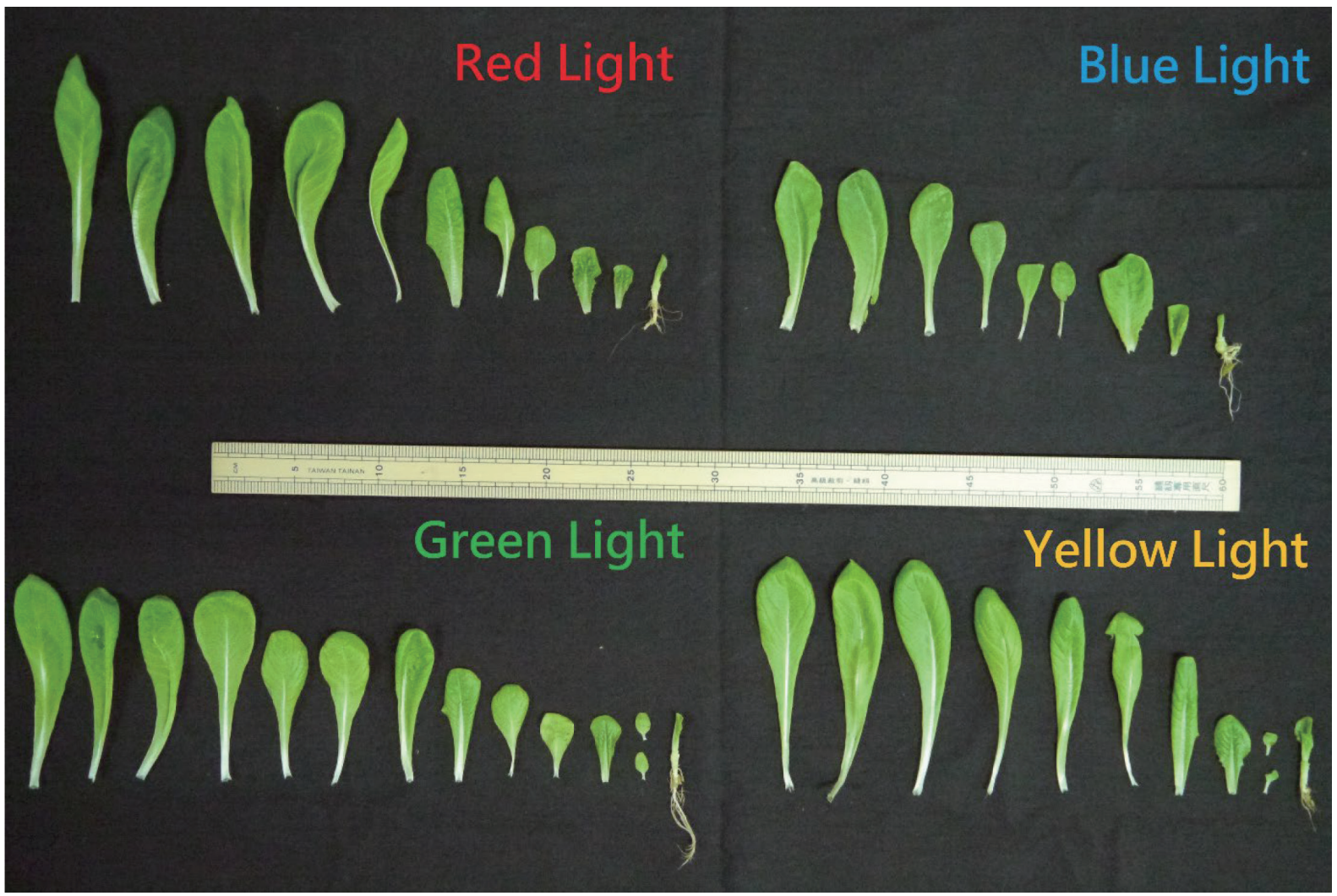

Fig. 1. Appearance and morphology of Boston lettuce leaves in monochromatic light-emitting diode light under a light intensity of $120 \mu \mathrm{mole} \cdot \mathrm{m}^{-2} \cdot \mathrm{s}^{-1}$ and $\mathrm{CO}_{2}$ concentration of $1000 \mathrm{ppm}$ for 15 days.

ferent spectral quality treatment of the Boston lettuce. The fresh weight of the lettuce with yellow light was $457.1 \mathrm{mg}$ on the 6th day, which was the lowest weight and presented a greater significant difference than let- tuce with other spectral qualities. This indicated that the demand for yellow light is the lowest among spectral qualities for plant growth. On the 9th day, the fresh weight of the lettuce with blue light was $1707.1 \mathrm{mg}$, and 
that of the lettuce with red light was $1279.5 \mathrm{mg}$. The dry weight of the lettuce that received blue light was $109.8 \mathrm{mg}$, and that of lettuce that received red light was $83 \mathrm{mg}$. There were significant differences between the lettuce that received these two spectral qualities. The fresh weight of the lettuce that received green light was $1415.1 \mathrm{mg}$, which presented no significant differences with that of the lettuce that received blue light and red light. This result indicated that green light influences plant growth. On the 12th day, the best plant growth performance was with red light, which produced lettuce weighing $4213.7 \mathrm{mg}$. This was significantly higher than the $3073.1 \mathrm{mg}$ of the lettuce that received blue light, $3053.3 \mathrm{mg}$ of the lettuce that received green light, and $2173.1 \mathrm{mg}$ of the lettuce that received yellow light. On the 15th day, the $7781 \mathrm{mg}$ fresh weight of the lettuce that received green light was significantly heavier than the $5467.6 \mathrm{mg}$ of the lettuce that received red light, $3938.6 \mathrm{mg}$ of the lettuce that received blue light, and $4185 \mathrm{mg}$ of the lettuce that received yellow light. The growth from yellow light was the lowest during the entire experiment. On the 6th day, the leaf lengths presented no significant differences regardless of spectral qualities. On the 9th day, the leaf length was $12.6 \mathrm{~cm}$ for the lettuce that received blue light, $12.5 \mathrm{~cm}$ for the lettuce that received green light, and $12.31 \mathrm{~cm}$ for the lettuce that received yellow light. The $11.46 \mathrm{~cm}$ leaf of the lettuce that received red light was significantly shorter than that of the other three. On the 12th day, the $16.04 \mathrm{~cm}$ leaf of the lettuce that received blue light was the longest, and the $14.93 \mathrm{~cm}$ leaf of the lettuce that received red light was the shortest. The two had significant differences. On the 15th day, the $18.97 \mathrm{~cm}$ leaf of the lettuce that received green light was longer than the
$17.52 \mathrm{~cm}$ leaf of the lettuce that received blue light and the $15.56 \mathrm{~cm}$ leaf of the lettuce that received red light. The three had significant differences. For leaf width, on the 6 th and 9th day, the leaf width was 2.52 and $3.68 \mathrm{~cm}$ for the lettuce that received blue light, and the leaf width was 2.02 and $2.59 \mathrm{~cm}$ for the lettuce that received yellow light. These two spectral qualities had significant differences. On the 12 th day, the widest leaf width was $5.03 \mathrm{~cm}$ for the lettuce that received blue light. It was $3.87 \mathrm{~cm}$ for the lettuce that received green light and $3.64 \mathrm{~cm}$ for the lettuce that received yellow light. The lettuce that received blue light differed significantly with the lettuce that received green and yellow light. On the 15th day, the widest leaf width was $5.57 \mathrm{~cm}$ for the lettuce that received green light and $4.38 \mathrm{~cm}$ for the lettuce that received red light. The two spectral qualities presented significant differences.

Table 3 and Fig. 2 indicate that the fresh weight of the Ziyan lettuce on the 6th day was heaviest at $95.1 \mathrm{mg}$ for the lettuce that received red light. This was significantly heavier than the $70.5 \mathrm{mg}$ of the lettuce that received blue light, $64 \mathrm{mg}$ of the lettuce that received green light, and $64.3 \mathrm{mg}$ of the lettuce that received yellow light. On the 9th day, the lowest weight was that of the lettuce that received blue light at $89.6 \mathrm{mg}$. This was significantly lower than the $169.2 \mathrm{mg}$ of the lettuce that received red light, $171.1 \mathrm{mg}$ of the lettuce that received yellow light, and $164 \mathrm{mg}$ of the lettuce that received green light. On the 12th day, the lettuce that received red light was the heaviest at $555.5 \mathrm{mg}$, and the lettuce that received yellow light was the lightest at $195.8 \mathrm{mg}$. On the 15th day, the lettuce that received red light was the heaviest at $2920.3 \mathrm{mg}$, and the lettuce that received yellow light was the lightest at $325.6 \mathrm{mg}$. These two

Table 3. Growth performance of Ziyan lettuce under a light intensity of $120 \mu \mathrm{mole} \cdot \mathrm{m}^{-2} \cdot \mathrm{s}^{-1}$ and $\mathrm{CO}_{2}$ concentration of 1000 ppm measured by day after planting and monochromatic light-emitting diode light

\begin{tabular}{|c|c|c|c|c|c|}
\hline $\begin{array}{c}\text { Days after } \\
\text { Planting } \\
\text { (Day) }\end{array}$ & Spectrum & $\begin{array}{c}\text { Fresh weight } \\
\text { (mg/plant) }\end{array}$ & $\begin{array}{l}\text { Dry weight } \\
\text { (mg/plant) }\end{array}$ & $\begin{array}{l}\text { Leaf length } \\
\text { (cm) }\end{array}$ & $\begin{array}{l}\text { Leaf width } \\
\text { (cm) }\end{array}$ \\
\hline \multirow{4}{*}{6} & Red & $95.1 \mathrm{a}^{2}$ & $7.6 \mathrm{a}$ & $5.37 \mathrm{a}$ & $1.92 \mathrm{ab}$ \\
\hline & Blue & $70.5 \mathrm{~b}$ & $6.6 \mathrm{a}$ & $3.69 \mathrm{~b}$ & $1.70 \mathrm{~b}$ \\
\hline & Green & $64.0 \mathrm{~b}$ & $4.7 \mathrm{~b}$ & $4.99 \mathrm{a}$ & $1.65 \mathrm{a}$ \\
\hline & Yellow & $64.3 \mathrm{~b}$ & $4.4 \mathrm{~b}$ & $5.78 \mathrm{a}$ & $1.56 \mathrm{a}$ \\
\hline \multirow{4}{*}{9} & Red & $169.2 \mathrm{a}$ & $15.1 \mathrm{ab}$ & $5.99 \mathrm{a}$ & $2.25 \mathrm{a}$ \\
\hline & Blue & 89.6 b & $9.7 \mathrm{~b}$ & $4.00 \mathrm{~b}$ & $1.69 \mathrm{a}$ \\
\hline & Green & $164.0 \mathrm{a}$ & $17.4 \mathrm{a}$ & $5.91 \mathrm{a}$ & $2.18 \mathrm{a}$ \\
\hline & Yellow & $171.1 \mathrm{a}$ & $15.5 \mathrm{a}$ & $6.96 \mathrm{a}$ & $2.15 \mathrm{a}$ \\
\hline \multirow{4}{*}{12} & Red & $555.5 \mathrm{a}$ & $50.3 \mathrm{a}$ & $10.70 \mathrm{a}$ & $2.98 \mathrm{a}$ \\
\hline & Blue & $251.4 \mathrm{bc}$ & $21.6 \mathrm{~b}$ & $6.66 \mathrm{~b}$ & $2.38 \mathrm{ab}$ \\
\hline & Green & $408.0 \mathrm{ab}$ & $40.3 \mathrm{a}$ & $9.24 \mathrm{ab}$ & $2.21 \mathrm{~b}$ \\
\hline & Yellow & $195.8 \mathrm{c}$ & $14.0 \mathrm{~b}$ & $10.44 \mathrm{a}$ & $1.99 \mathrm{~b}$ \\
\hline \multirow{4}{*}{15} & Red & $2920.3 \mathrm{a}$ & $256.7 \mathrm{a}$ & $21.38 \mathrm{a}$ & $9.23 \mathrm{a}$ \\
\hline & Blue & $1759.6 \mathrm{~b}$ & $173.0 \mathrm{a}$ & $14.27 \mathrm{~b}$ & $8.17 \mathrm{a}$ \\
\hline & Green & $2715.3 \mathrm{ab}$ & $241.0 \mathrm{a}$ & $19.48 \mathrm{ab}$ & $9.22 \mathrm{a}$ \\
\hline & Yellow & $325.6 \mathrm{c}$ & $24.0 \mathrm{~b}$ & $15.14 \mathrm{ab}$ & $3.26 \mathrm{~b}$ \\
\hline
\end{tabular}

${ }^{\mathrm{z}}$ Mean separation within the same column followed by different lowercase letters were significantly different $(\mathrm{p}<0.05)$, as determined through Scheffe's multiple range test. 


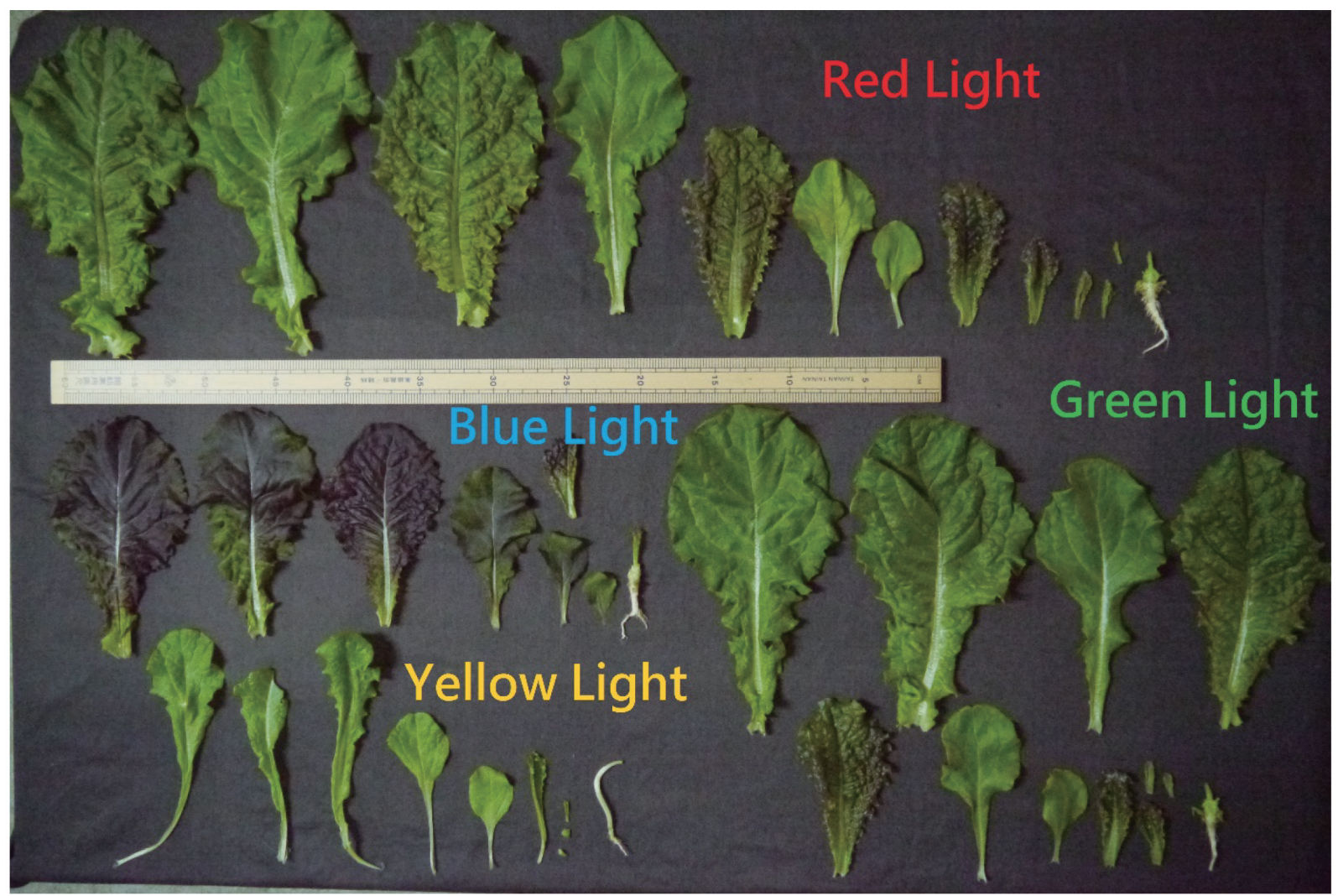

Fig. 2. Appearance and morphology of Ziyan lettuce leaves in monochromatic light-emitting diode light under a light intensity of $120 \mu \mathrm{mole} \cdot \mathrm{m}^{-2} \cdot \mathrm{s}^{-1}$ and $\mathrm{CO}_{2}$ concentration of $1000 \mathrm{ppm}$ for 15 days.

spectral qualities presented significant differences. On the 6th day, the lettuce that received red light had the heaviest dry weight at $7.6 \mathrm{mg}$, which was significantly heavier than the $4.7 \mathrm{mg}$ of the lettuce that received green light and the $4.4 \mathrm{mg}$ of the lettuce that received yellow light. This indicated that the demand for red light is the greatest for the initial growth performance of Ziyan lettuce. On the 9 th day, the lettuce that received blue light had a lower dry weight at $9.7 \mathrm{mg}$ than the lettuce that received green light (17.4 mg), the lettuce that received red light $(15.1 \mathrm{mg})$, and the lettuce that received yellow light $(15.5 \mathrm{mg})$, with no significant difference. On the 12th day, the lettuce that received red light had a heavier weight of $50.3 \mathrm{mg}$ than did the lettuce that received blue light $(21.6 \mathrm{mg})$ and the lettuce that received yellow light (14 mg). On the 15th day, the lettuce that received red light had a greater weight at $256.7 \mathrm{mg}$ than did the lettuce that received blue light (173 mg) and the lettuce that received yellow light (24 mg). The weight of the lettuce that received red light was significantly higher than the lettuce that received the other three types of light. The leaf length of the lettuce that received yellow light was the longest on the 6th and 9th day was the longest at 5.78 and $6.96 \mathrm{~cm}$, respectively. On the 9th day, the lettuce that received blue light had the shortest leaf length at $4 \mathrm{~cm}$. On the 12th day, the lettuce that received red light had the longest leaf length at $10.7 \mathrm{~cm}$, followed by the lettuce that received yellow light at $10.44 \mathrm{~cm}$. On the $15 \mathrm{th}$ day, the lettuce that received red light had the longest leaf length at $21.38 \mathrm{~cm}$, followed by the lettuce that received green light at $19.48 \mathrm{~cm}$. The leaf width of the lettuce that received red light on the 6th day and 9th day was the widest at 1.92 and $2.25 \mathrm{~cm}$, respectively. However, compared to the other three spectral qualities, no significant difference appeared. On the 12th day, the lettuce that received red light had the widest leaf width at $2.98 \mathrm{~cm}$, which significantly differed with the $2.21 \mathrm{~cm}$ of the lettuce that received green light and the $1.99 \mathrm{~cm}$ of the lettuce that received yellow light. On the 15th day, the lettuce that received red light had the widest leaf width at $9.23 \mathrm{~cm}$, which significantly differed with the $3.26 \mathrm{~cm}$ of the lettuce that received yellow light.

\section{Photosynthetic efficiency analysis of LEDs with single spectral qualities}

The photosynthetic efficiency of the two cultivarsBoston lettuce and Ziyan lettuce-were investigated under different light intensity and $\mathrm{CO}_{2}$ concentration. With a $\mathrm{CO}_{2}$ concentration of $400 \mathrm{ppm}$, photosynthesis required a light intensity of at least $80 \mu \mathrm{mole} \cdot \mathrm{m}^{-2} \cdot \mathrm{s}^{-1}$ under red or blue light and $100 \mu \mathrm{mole} \cdot \mathrm{m}^{-2} \cdot \mathrm{s}^{-1}$ under green or yellow light (Figs. 3 and 4). This indicated that plants are more sensitive to red and blue light than green and yellow light for photosynthesis. However, when the light intensity was $40 \mu \mathrm{mole} \cdot \mathrm{m}^{-2} \cdot \mathrm{s}^{-1}$, the Boston lettuce required a $\mathrm{CO}_{2}$ concentration of 1000 ppm for photosynthesis (Fig. 3), whereas the Ziyan lettuce only required $800 \mathrm{ppm}$ (Fig. 4). The influence of difference spectral qualities on the photosynthetic effi- 


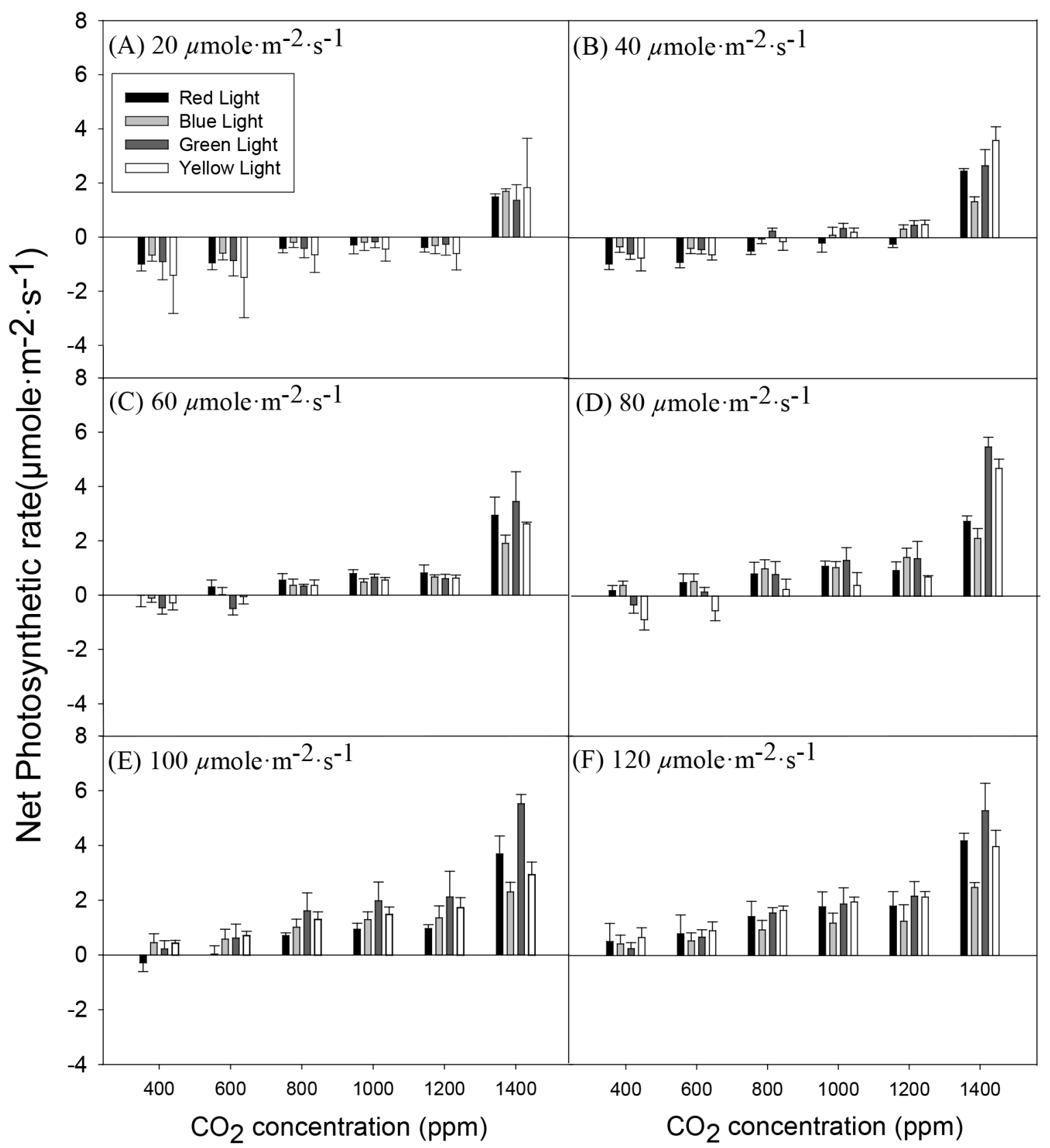

Fig. 3. Effects of light intensity, monochromatic light-emitting diode light, and $\mathrm{CO}_{2}$ concentration on the photosynthetic efficiency of Boston lettuce.

ciency of the Boston lettuce was compared at a light intensity of $120 \mu \mathrm{mole} \cdot \mathrm{m}^{-2} \cdot \mathrm{s}^{-1}$ and $\mathrm{CO}_{2}$ concentrations of 400, 600, 800, and $1000 \mathrm{ppm}$. With the same $\mathrm{CO}_{2}$ concentration across spectral qualities, photosynthetic efficiency was the highest under yellow light. This indicated that under yellow light, light intensity was more important for photosynthetic efficiency than $\mathrm{CO}_{2}$ concentration. When $\mathrm{CO}_{2}$ concentration increased to 1200 and $1400 \mathrm{ppm}$ with a light intensity of 100 and $120 \mu \mathrm{mole} \cdot \mathrm{m}^{-2} \cdot \mathrm{s}^{-1}$, the photosynthetic efficiency was the highest at $5.53 \mu \mathrm{mole} \cdot \mathrm{m}^{-2} \cdot \mathrm{s}^{-1}$ under green light. This was more than twice the $2.3 \mu \mathrm{mole} \cdot \mathrm{m}^{-2} \cdot \mathrm{s}^{-1}$ under blue light. With the lowest demand for light intensity at $60 \mu \mathrm{mole} \cdot \mathrm{m}^{-2} \cdot \mathrm{s}^{-1}$ and the $\mathrm{CO}_{2}$ concentration at 600 1200 ppm, photosynthetic efficiency was highest under red light. With a light intensity of $80 \mu \mathrm{mole} \cdot \mathrm{m}^{-2} \cdot \mathrm{s}^{-1}$ and a $\mathrm{CO}_{2}$ concentration of 400-800 ppm, photosynthetic efficiency was highest under blue light. Therefore, under different light intensity and $\mathrm{CO}_{2}$ concentration, red and blue light are the most critical spectral qualities for plant growth and photosynthetic efficiency in Boston lettuce and Ziyan lettuce. In addition, the demand for light intensity is higher than that for $\mathrm{CO}_{2}$ concentration under red light, followed by blue light (Figs. 3 and 4).

Regarding the influence of spectral qualities on the photosynthetic efficiency of Ziyan lettuce, photosynthesis required a light intensity of $80 \mu \mathrm{mole} \cdot \mathrm{m}^{-2} \cdot \mathrm{s}^{-1}$ and a $\mathrm{CO}_{2}$ concentration of $400 \mathrm{ppm}$ under red, blue, and yellow light. Among these, red light caused photosynthesis to occur the earliest. Photosynthesis began under a light 


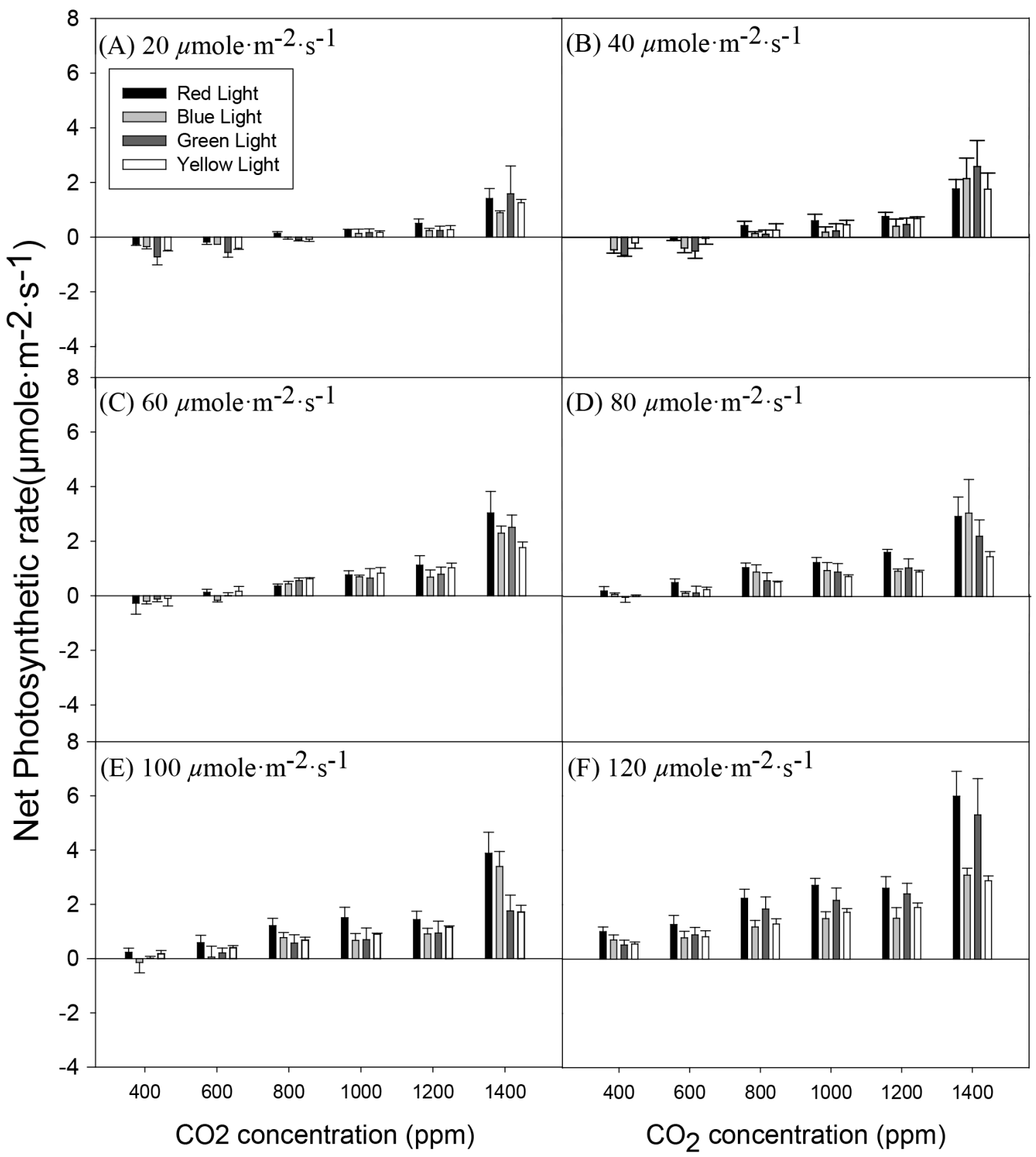

Fig. 4. Effects of light intensity, monochromatic light-emitting diode light, and $\mathrm{CO}_{2}$ concentration on the photosynthetic efficiency of Ziyan lettuce.

intensity of $20 \mu \mathrm{mole} \cdot \mathrm{m}^{-2} \cdot \mathrm{s}^{-1}$ and a $\mathrm{CO}_{2}$ concentration of over 800 ppm under red light. When the intensity of yellow light increased from 60 to $80 \mu \mathrm{mole} \cdot \mathrm{m}^{-2} \cdot \mathrm{s}^{-1}$ with a $\mathrm{CO}_{2}$ concentration of 800-1400 ppm, photosynthetic efficiency decreased. With a $\mathrm{CO}_{2}$ concentration of $1400 \mathrm{ppm}$, photosynthetic efficiency decreased from 1.77 to $1.46 \mu \mathrm{mole} \cdot \mathrm{m}^{-2} \cdot \mathrm{s}^{-1}$. This indicated that the demand for yellow light may be lower for plant growth (Fig. 4). However, under a light intensity at 100 and $120 \mu \mathrm{mole} \cdot \mathrm{m}^{-2} \cdot \mathrm{s}^{-1}$ and $\mathrm{CO}_{2}$ concentration of $1200 \mathrm{ppm}$, photosynthetic efficiency under yellow light was slightly higher than that under blue light, although this was not significantly different. These results suggested that under a light intensity of 100 and $120 \mu \mathrm{mole} \cdot \mathrm{m}^{-2} \cdot \mathrm{s}^{-1}$ and
$\mathrm{CO}_{2}$ concentration over $400 \mathrm{ppm}$, Ziyan lettuce had higher demand for red light.

\section{DISCUSSION}

Researchers have indicated that the spectral qualities required for plant growth are mainly red and blue light (Rabara et al., 2017; Renata et al., 2013; José et al., 2002; Li et al., 2012; Zheng and Marie-Christine, 2017; Lichtenthaler et al., 1980). For the initial growth of the Boston lettuce on the 6th day of this experiment, both the fresh and dry weight of the lettuce that received red light were heavier than those that received blue, green, or yellow light. This indicated that red light is a neces- 
sary spectral quality for the initial growth of plants. Rabara et al. (2017) stated that red light is an important influence on the growth and development of artichoke seedlings. Chen et al. (2014b) stated that red light can increase the biomass and stem thickness of JuhuaXiaobaye savoy, whereas blue light has the opposite effect, which aligned with the results of our experiment. On the 9th day, blue light treatment was found to result greater fresh weight, dry weight, and leaf length and width than treatment with the other three spectral qualities. Hernández and Kubota (2016) used LEDs to evaluate the physiological reactions of Cucumis sativus seedlings to different ratios of blue- and red-light photon fluxes. The results revealed that the hypocotyl that underwent red light treatment was longer than the hypocotyls that received different ratios of red and blue light mixtures. The plant height under blue light treatment was taller than that under red and blue light mixtures with different ratios. The results of this experiment were similar. Red light facilitated the growth of artichoke seedlings (Rabara et al., 2017). Blue light inhibited the elongation of rice seedling stems (Chen et al., 2014a). It also inhibited the growth of tomato seedlings and reduced their chlorophyll content (Wang et al., 2017). In this experiment, similar results occurred with the Ziyan lettuce (Table 3). In addition, blue light facilitated leaves to change colors, and yellow light caused the plants to become thin and long (Fig. 2).

Regcarding the photosynthetic efficiency of the Boston lettuce under different light intensity and $\mathrm{CO}_{2}$ concentration in this experiment, the photosynthetic efficiency of green light was highest under a light intensity of $100 \mu \mathrm{mole} \cdot \mathrm{m}^{-2} \cdot \mathrm{s}^{-1}$ and $\mathrm{CO}_{2}$ concentration over 1000 ppm (Fig. 3). Terashima et al. (2009) discovered that green light could penetrate leaves better than could red or blue light in a spinach experiment. They used different spectral quality treatments with green, red, or blue light in a white light environment, and the green light increased photosynthetic efficiency the most because green leaves have large amounts of chlorophyll. They can adapt to low-efficiency Ribulose-1,5-bisphosphate carboxylase (Rubisco) and provide suitable spectral quality to the chloroplast. By absorbing chlorophyll with green light at a low light intensity, the mesophyll structure is modified, and the ratio of Rubisco and chlorophyll is adjusted. Thus, the photosynthetic effective radiation absorptivity of the leaves increases, and photosynthesis inside the chloroplast occurs. The results of this experiment may be related to this mechanism.

For Boston lettuce under a light intensity of $60 \mu \mathrm{mole} \cdot \mathrm{m}^{-2} \cdot \mathrm{s}^{-1}$ and $\mathrm{CO}_{2}$ concentration of $600 \mathrm{ppm}$, red light treatment caused photosynthetic efficiency earlier than did other spectral qualities (Fig. 3). McCree (1972) used relative quantum efficiency to analyze the stimulation of photosynthetic efficiency in plants with different single spectral qualities. Of all spectral qualities, red light was verified to have the lowest luminous efficiency and the highest relative quantum efficiency, which facilitated the fastest absorption for plants. In this experiment, the Boston lettuce produced similar results under a low light intensity. Under a light intensity of $100 \mu \mathrm{mole} \cdot \mathrm{m}^{-2} \cdot \mathrm{s}^{-1}$ and $\mathrm{CO}_{2}$ concentration over $1200 \mathrm{ppm}$, green light had the highest photosynthetic efficiency. Under a light intensity of $20 \mu \mathrm{mole} \cdot \mathrm{m}^{-2} \cdot \mathrm{s}^{-1}$ and $\mathrm{CO}_{2}$ concentration of $1400 \mathrm{ppm}$ or light intensity of $120 \mu \mathrm{mole} \cdot \mathrm{m}^{-2} \cdot \mathrm{s}^{-1}$ and $\mathrm{CO}_{2}$ concentration of 400-1000 ppm, yellow light produced a higher photosynthetic efficiency than did the other three spectral qualities. However, the fresh and dry weights were lower. This indicated that yellow light has no direct influence on yield. Folta and Maruhnich (2007) reported that green light influences growth and development, flowering, stoma opening and closing, stem growth, chloroplast genes, and plant growth regulation. A spectrum of green light of 500-600 nm should contain $580-600 \mathrm{~nm}$ of yellow light. Under certain conditions, yellow light may have a higher photosynthetic efficiency because of green light. The results of this experiment agreed with this finding.

For Boston lettuces, under a light intensity of $80 \mu \mathrm{mole} \cdot \mathrm{m}^{-2} \cdot \mathrm{s}^{-1}$ and $\mathrm{CO}_{2}$ concentration of $400-1000 \mathrm{ppm}$, blue light resulted in the highest photosynthetic efficiency among spectral qualities. However, when the light intensity increased to 100 and $120 \mu \mathrm{mole} \cdot \mathrm{m}^{-2} \cdot \mathrm{s}^{-1}$, photosynthetic efficiency ebbed. Muneer et al. (2014) compared the influence of red light at $88 \mu \mathrm{mole} \cdot \mathrm{m}^{-2} \cdot \mathrm{s}^{-1}$, blue light at $80 \mu \mathrm{mole} \cdot \mathrm{m}^{-2} \cdot \mathrm{s}^{-1}$, and green light at $70 \mu \mathrm{mole} \cdot \mathrm{m}^{-2} \cdot \mathrm{s}^{-1}$ at a $\mathrm{CO}_{2}$ concentration identical to that of outdoors on the growth of lettuce. The results showed that blue light facilitated plant growth, which was similar to the results of this experiment (Fig. 3). When light intensity increases from 80 to $100 \mu \mathrm{mole} \cdot \mathrm{m}^{-2}$ - $\mathrm{s}^{-1}$ under an identical $\mathrm{CO}_{2}$ concentration, the Ziyan lettuce presented similar results. This indicated that little blue light was required for the growth of the two cultivars of lettuce.

For Ziyan lettuce, red light generally resulted in a higher photosynthetic efficiency, which indicated that Ziyan lettuce of the red leaf cultivar has a certain requirement for red light. Son and Oh (2013) noted that for L. sativa L. "Sunmang" with different ratios of red and blue light mixtures, fresh weight, dry weight, and leaf area increased with increasing red light ratios. In addition, Folta and Childers (2008) found that red light could convert inactive phytochromes to the active state, which caused the plasmid in the lettuce to develop and activated chloroplast and cell nucleus gene expressions. The results of this study were similar to those of these two studies.

In addition, this experiment suggested that under a light intensity of $60 \mu \mathrm{mole} \cdot \mathrm{m}^{-2} \cdot \mathrm{s}^{-1}$ and $\mathrm{CO}_{2}$ concentration of 600-1000 ppm, yellow light produces a higher photosynthetic efficiency than did other spectral qualities (Fig. 4). This indicated that although yellow light is not as crucial as red and blue light for plant growth, it still exhibits some influence. If red and blue light are mixed at a proper ratio, photosynthetic efficiency can increase.

This experiment used different combinations of light intensity and $\mathrm{CO}_{2}$ concentration to investigate the photosynthetic efficiency, fresh weight, and dry weight of the two cultivars of lettuce. The results revealed that the 
influence of the four different single spectral qualities on photosynthetic efficiency and on yield is not consistent but depends on the type of lettuce. Regarding the fresh and dry weights of plants seeded and harvested in environments with a light intensity of $120 \mu \mathrm{mole} \cdot \mathrm{m}^{-2} \cdot \mathrm{s}^{-1}$ and $\mathrm{CO}_{2}$ concentration of $1000 \mathrm{ppm}$, Boston lettuce had a higher weight under green light with significant differences from lettuce under other spectral qualities. Yellow light produced a higher photosynthetic efficiency but no significant differences occurred compared to other spectral qualities. For Ziyan lettuce, red light produced the highest fresh weight, dry weight, and photosynthetic efficiency. Son and Oh (2013) stated that the cumulation of plant metabolites differs by plant cultivars and spectral qualities. Single spectral quality treatments can stimulate the accumulated biomass of lettuce but can easily cause leaf shape anomalies. In addition, they have a negative influence on their polyphenols and antioxidation abilities. This experiment tested the influences and requirements of single spectral quality LEDs on the growth and photosynthetic efficiency of two lettuce cultivars. In the future, mixed spectral qualities can be discussed as a reference for plant factories to produce lettuce and increase yields.

\section{AUTHOR CONTRIBUTIONS}

1. Chun-Yu Tsai, verified that the lettuce cultivars had different appearances under different single spectral quality treatments. Fresh weight, dry weight, and photosynthetic efficiency were analyzed to reveal the influence of single spectral qualities on lettuce yield. This was conducive to understanding the influence and requirements of the growth and photosynthetic efficiency of the lettuce cultivars.

2. Yung-Fu Yen, designed the analytic method for the effects of single spectral qualities on lettuce growth by using the concept of lettuce cultivars and provided advice.

3. Chyung Ay, designed the suitable lettuce growing space from the environment control basis of plant factories and provided advice on environment usage control.

4. Ikuo Miyajima, provided practical research advice on spectral qualities and lettuce cultivars and revised the study content and experiment data.

5. Kuang-Liang Huang, integrated the test programs of single spectral quality treatments for lettuce cultivars from former studies on lettuce cultivar types and managed related studies in the laboratory.

\section{REFERENCES}

Chen, C. C., M. Y. Huang, K. H. Lin, S. L. Wong, W.D. Huang and C. M. Yang 2014a Effects of light quality on the growth, development and metabolism of rice seedlings (Oryza sativa L.). Res. J. Biotechnol., 9: 15-24

Chen X. W., S. Q. Liu, Y. Wang, J. K. Liu and L. Feng 2014b Effects of different LED light qualities on growth, photosynthetic characteristics and nutritional quality of savoy. Chinese J. Ecol., 25(7): 1955-1962
Dutta G., S. 2017 Light Emitting Diodes for Agriculture. Springer Verlag, Singapore.

Folta, K. M. and K. S. Childers 2008 Light as a growth regulator: controlling plant biology with narrow-bandwidth solid-state lighting systems. HortScience, 43(7): 1957-1964

Folta, K. M. and S. A. Maruhnich 2007 Green light: a signal to slow down or stop. J. Exp. Bot., 58(12): 2009-3111

Hernández, R. and C. Kubota 2016 Physiological responses of cucumber seedlings under different blue and red photon flux ratios using LEDs. Environ. Exp. Bot, 121: 66-74

Hernández, R. and C. Kubota 2012 Tomato seedling growth and morphological responses to supplemental LED lighting red: blue ratios under varied daily solar light integrals. Acta Hortic., 956: $187-194$

José, C. R., N. C. Marques, J. N. Semedo, M. C. Matos and V. L. Quartin 2002 Photosynthetic performance and pigment composition of leaves from two tropical species is determined by light quality. Plant Biol., 4(1): 112-120

Li, H., C. Tang, Z. Xu, X. Liu and X. Han 2012 Effects of different light sources on the growth of non-heading Chinese cabbage (Brassica campestris L.). J. Agric. Sci., 4: 262-273

Lin, S. I., C. Y. Chang, M. L. Kuo and H. F. Lo 2016 Study on hydroponically cultivated crisphead lettuce (Lactuca sativa L. var. capitata) in closed-type plant factory. J. Taiwan Soc. Hort. Sci, 62(1): 17-32

Louis, A., A. J. Both and A. J. Chiu 2000 Controlling greenhouse light to a consistent daily integral. Trans. ASAE, 43: 421-431

Lichtenthaler, H.K., C. Buschmann and U. Rahmsdorf 1980 The importance of blue light for the development of sun-type chloroplasts. Blue Light Syndrome, 485-494

McCree, K.J. 1972 The action spectrum, absorptance and quantum yield of photosynthesis in crop plants. Agric. Meteorol., 9: $191-216$

Mizuno, T., W. Amaki and H. Watanabe 2011 Effects of monochromatic light irradiation by LED on the growth and anthocyanin contents in laves of cabbage seedlings. Acta Hortic., 907: 179-184

Muneer, S., E. J. Kim, J. S. Park and J. H. Lee 2014 Influence of green, red and blue light emitting diodes on multiprotein complex proteins and photosynthetic activity under different light intensities in lettuce leaves (Lactuca sativa L.). Int. J. Mol. Sci., 15: 4657-4670

Olle, M. and A. Vkvile 2013 The effects of light-emitting diode lighting on greenhouse plant growth and quality. Agric. Food Sci., 22: 223-234

Pettersen, R. I., S. Torre and H. R. Gislerød 2010 Effects of intracanopy lighting on photosynthesis characteristics in cucumber. Sci. Hortic., 125: 77-81

Rabara, R. C., G. Behrman, T. Timbol and P. J. Rushton 2017 Effect of spectral quality of monochromatic LED lights on the growth of artichoke seedlings. Front. Plant Sci., 8: 190

Renata, W., A. Kołton, O. Długosz-Grochowska, M. Żupnik and W. Grzesiak 2013 The effect of LED lighting on photosynthetic parameters and weight of lamb's lettuce (Valerianella locusta). Folia Hort., 25: 41-47

Stutte, G., S. Edney and T. Skerritt 2009 Photoregulation of bioprotectant content of red leaf lettuce with light-emitting diodes. HortScience, 44: 79-82

Son, K. H. and M. M. Oh 2013 Leaf shape, growth, and antioxidant phenolic compounds of two lettuce cultivars grown under various combinations of blue and red light-emitting diodes. HortScience, 48: 988-995

Terashima, I., T. Fujita., T. Inoue, W. S. Chow and R. Oguchi 2009 Green light drives leaf photosynthesis more efficiently than red light in strong white light: revisiting the enigmatic question of why leaves are green. Plant Cell Physiol., 50: 684-697

Van Iersel, M. W. and D. Gianino 2017 An adaptive control approach for LED lights can reduce the energy costs of supplemental lighting in greenhouses. HortScience, 52: 72-77

Xu, D. Q., W. Gao and J. Ruan 2015 Effect of light quality on plant growth and development [J]. Plant Physiol. J., 51(8): 1217-1234 
Wang L. W., Y. Li, G. F. Xin, M. Wei, Q. H. Mi and Q. C. Yang 2017 Effects of different proportions of red and blue light on the growth and photosynthesis of tomato seedlings. Chinese J. Ecol., 28(5): 1595-1602
Zheng, L. and V.L. Marie-Christine 2017 Long-Term effects of red- and blue-light emitting diodes on leaf anatomy and photosynthetic efficiency of three ornamental pot plants. Front Plant Sci., 8: 1-12 